\title{
CAUGHT IN THE IRONS: ONE OF THE LIVED EXPERIENCES OF LONG-TERM OCEAN CRUISING WOMEN
}

\author{
GAYLE R. JENNINGS \\ Griffith Business School, Griffith University, Gold Coast Campus, Queensland, Australia
}

\begin{abstract}
One of the reasons why women participate in long-term ocean cruising is because of relationship commitments. During 1992-1999 and 2000-2003, ethnographic studies informed by the traditions of symbolic interactionism, phenomenology, ethnomethodology, and feminist inquiry were conducted. Materials collected were analyzed using grounded theory and the Pamphilon zoom model. A Marxist/socialist feminist critique emerged from the interpretation of empirical materials. This critique demonstrated that some women had a lived experience that involved exploitation, marginalization, powerlessness, and cultural imperialism. The experience relegated them to the domestic sphere of the cruising/sailing enterprise as well as excluded them from decision making as they were psychically and economically dependent on their cruising partners. However, the cruising women argued that such a critique avoided the issue of affect or that women can be both subjects and agents. Subsequently, the cruising women were engaging in empowered connectivity (i.e., choosing with whom and what they wished to stay connected). The study provides an example of a holistic, interdisciplinary, qualitative study of independent travel that makes visible the lived experiences of cruising women traveling because of relationships.
\end{abstract}

Key words: Ethnography; Participant observation; Feminist perspectives; Empowered connectivity; Australia

\section{Introduction}

Long-term ocean cruisers are self-defined as people who have accepted, adopted, or chosen a cruising lifestyle, who live aboard their own sailing vessels, have independent means, are self-sufficient, and have been away from their port of departure for an extended period of time. As a group, cruisers may be classified as a subculture (Macbeth, 1985) that engages in long-term independent traveling. In particular, as a subculture, cruisers have their own mores, language, values, and avenues for access. It should be noted that while cruisers are a subculture they differ from the land-based alternative lifestyle participants in that cruisers do not adopt a communal lifestyle (Macbeth, 1985). A semblance of com-

Address correspondence to Dr. Gayle R. Jennings, Department of Tourism, Leisure, Hotel and Sport Management, Griffith Business School, Griffith University, Gold Coast Campus, Queensland, Australia. Tel: (61) 7 55528798;; Fax: (61) 7 55528507; E-mail: g.jennings@griffith.edu.au 
munity occasionally occurs when cruisers choose to travel loosely together through questionable waters for safety reasons rather than for a sense of community. Sometimes a communal lifestyle of a shortterm nature eventuates when cruisers are in port or at a mooring and fortune brings kindred souls together. Thus, cruisers do not demonstrate communal lifestyle living patterns.

To date, studies into the cruising community and subculture have been limited with Macbeth (1985 and other related works) being the main researcher, albeit investigating cruisers as an amorphous group. While there have been studies undertaken into yacht chartering (Lett, 1983; Linington, 1998; Richens, 1992), this is essentially a different activity as the charters are usually short term in nature and the vessel is owned by someone else. Further, studies of the lived experiences of women involved in racing sailing vessels are also limited (e.g., Bricknell, 1999; Crawley, 1998). Although there are some similarities between the lived experiences of racing and cruising women, the nature of the two activities is different in terms of purpose, time, distance, ownership of vessels, monitoring procedures, as well as support structures.

In order to build on the 1985 work of Macbeth, this aticle will focus on long-term ocean cruising women, and in particular, those women who are metaphorically perceived to be "caught in the irons." This will highlight the gendered nature of the cruising subculture as well as the long-term independent travel experiences incorporated into cruising lifestyles. The term "caught in the irons" refers to a state when a sailing vessel is facing into the direction of the wind, is depowered and generally unable to make forward movement under sail until corrected. It also refers to being put into leg shackles. In the context of this article, "caught in the irons" refers to women who do not want to be cruising. These women have simultaneously suspended (halted forward movement) the pursuit of their "life plan" (Dreikurs, 1953) goals and are "shackled" to their partners' life plan goals. It must be emphasized that while these women are cruising, they would prefer not to be doing so. They are cruising "because of" love and belonging. As a consequence, the purpose of this article is threefold.

First, the article provides insight into the lived experiences of long-term ocean cruising women who go cruising "because of" (Schutz, 1967) relationship commitments. Schutz identifies two bases for social action between people: "because of" (WeilMotiv) and "in-order-to" (Um-zu-Motiv) motives. Based on self-reports by the cruising women involved in this study, relationship commitments arise because of love for, as well as being or belonging with, their partners as a result of marriage or a past commitment to a long-term personal relationship. Subsequently, their cruising is predicated upon social actions based in the past as opposed to futureoriented action associated with an "in-order-to" project-based motive, such as to go traveling. This article elaborates on one part of a wider study of long-term ocean cruisers that investigated why people chose to adopt a cruising lifestyle (Jennings, 1999). In summary, the wider study found that cruisers were motivated by a variety of extrinsic and intrinsic motivations, as well as by their social background and status in society. They were motivated by a need to escape the pressures and constraints of their home society, as well as to pursue a lifestyle that offered freedom and a sense of personal control, and a need to add some adventure or challenge to their lives or to fulfill a dream. Cruisers were also motivated by relationship commitments and/or a desire to travel and experience new cultures, people, and settings. Their age, gender, family life cycle stage, education, income, and former lifestyle pursuits were noted by the participants in the study as additional motivating factors.

The second aim of this article is to provide an example of a qualitative study informed by the interpretive social sciences paradigm, which utilized ethnography as well as grounded theory as the basis for interpretation and theory generation. In providing such an example, the article simultaneously provides a model of the use of a narrative script to report the research findings as opposed to the usual genre of a scientific report. It is important to note that as a consequence of using grounded theory the literature review is incorporated in later sections of the article that deal with the interpretation of the "findings." In these later sections, readers will encounter literature drawn from Marxist/socialist writings associated with subordination, oppression, psychical and economic dependence, exploitation, marginalization, powerlessness, cultural imperialism, equality, power, agency, and affect. Third, this 
article serves to make visible the experience of women involved in long-term travel experiences. This adds to the growing body of tourism and travel literature investigating tourism and travel from a gendered perspective, women's perspectives in particular.

Having presented the three aims of the article, it is important to iterate that out of the multiplicity of reasons for adopting a cruising lifestyle, this article draws on the empirical findings related to relationship commitments as the primary motivation for traveling and engaging in a long-term ocean voyage by women; specifically, long-term ocean cruising women who participated in the ethnographic study conducted from 1992 to 1999 and a subsequent follow-up ethnographic study from 2000 to 2003 . To further situate the focus of this article, additional background regarding the sociodemographics of long-term ocean cruising will be provided.

\section{Background on Sociodemographics of Long-term Ocean Cruisers}

Cruisers' propensity to travel aboard their own yachts has not changed greatly since Macbeth's (1985) study. Their propensity is attributed to their mature ages, their current stage within the family life cycle, their education, employment (Table 1), income, Western lifestyles, and resultant attitudes to work and leisure.

The investment by cruisers in their vessels is substantial. Vessel prices ranged from AUS $\$ 30,000$ to AUS $\$ 600,000$, and annual cruising budgets ranged from AUS $\$ 4,000$ to AUS\$73,000. The cruisers in this study were primarily Australian, American, New Zealand, and British citizens or citizens from other European countries. Having presented sociodemographics, I will now outline the theoretical paradigm, which informed the study and the methods used to gather and interpret the empirical materials used in the course of this study.

\section{The Theoretical Paradigm Informing the Study}

In this section I will address, in turn, the theoretical paradigm that informed this study and its related ontology, epistemology, methodologies, axiology, and associated methods. My research was guided by the interpretive social sciences paradigm, defined by Guba (1990) as the constructivist paradigm. Specifically, this "paradigm assumes a relativist ontology (there are multiple realities), a subjectivist epistemology (knower and subject create understandings), and a naturalistic (in the natural world) set of methodological procedures" (Denzin \& Lincoln, 2000a, p. 21). An interpretive social science paradigm was selected because of the belief that the insider's view provides the best lens through which to understand the lived experiences of cruising women who participated in this study. In particular, the insider's view or the emic perspective allows for the identification of multiple realities (Fetterman, 1989), as evidenced by the previously stated multiplicity of motivations for becoming a long-term ocean cruiser. Further, as an insider, the researcher on entering the social setting and becoming one of the social actors in that social setting (Blumer, 1962) develops an autobiography upon which to jointly construct meaning of the women's lived experiences. Such a subjectivist epistemological approach to the construction of knowledge regarding the social reality of the cruising women is founded on the belief that:

the sociology of knowledge must first of all concern itself with what people "know" as "reality" in their everyday, non- or pre-theoretical lives. In other words, common-sense "knowledge" rather than "ideas" must be the central focus for the sociology of knowledge. It

Table 1

Overview of Sociodemographic Details of Cruisers

\begin{tabular}{lll}
\hline Sociodemographics & \multicolumn{1}{c}{ Women } \\
\hline Age (range in years) & Early 20s to late 60s & Early 20s to late 70s \\
Age (mode in years) & $40-59$ & $40-59$ \\
Family life cycle (mode) & "Retired"; traveling without young children & "Retired"; traveling without young children \\
Level of Education (mode) & Completed tertiary education & Completed tertiary education \\
Type of Employment (mode) & Professionals (e.g., teachers, editors, counselors) & Employers; Professionals; Skilled manual workers \\
\hline
\end{tabular}


is precisely this "knowledge" that constitutes the fabric of meanings without which no society could exist. (Berger \& Luckman, 1981, p. 27)

This belief is also reflected in feminist thought, as Harding (1991) noted: "all scientific knowledge is always, in every respect, socially situated" (p. 10). Such socially situated knowledge is described by Haraway (1988) as "situated knowledges" to remind us as researchers that multiple realities exist within the one social setting and as researchers we must enter those settings in order to understand those realities.

Given the third aim of the study was to make visible the experiences of women, the principles of feminist methodology also informed my research design. This is listed below and draws on the writing of Cook and Fonow (1990, pp. 72-80) and others:

- Acknowledgment that social knowledge has been primarily framed by men about men and women's experiences have been silenced. As a consequence, women's experiences need to be given voice through study and interpretation.

- Focus on consciousness-raising of the researcher and participants, including the incorporation of consciousness-raising techniques within research projects.

- "Rejection of the subject/object separation" in research processes (Harding, 1991, pp. 138163; Westkott, 1990, pp. 60-61).

- "Examination of ethical concerns" (Cook \& Fonow, 1990, pp. 72-80).

- "Emphasis on empowerment and transformation" (Cook \& Fonow, 1990, pp. 72-80).

In presenting such a list I do not mean to assert that there is either a hegemonic feminist theory (Sandoval, n.d., cited in King, 1990) or a hegemonic feminist methodology. For as Reinharz (1992) comments, "the fact that there are multiple definitions of feminism means that there are multiple feminist perspectives on social research methods" (p. 241). More specifically, the singular form is used to "emphasize the generic and transitive nature of both" (Hirsch \& Keller, 1990, p. 2) theory and methodology. Moreover, in using the term, I am identifying the standpoint I adopted for the research, which is a synthesis of "the world of the discipline, academy ... and the world of feminist scholarship" (Reinharz, 1992, p. 243).

As well as a feminist methodology, due to the study's interpretive paradigm (see the second aim of the study), a qualitative methodology was also used. Specifically, my qualitative methodology drew on the domains of:

- Symbolic interactionism, which aims to understand how people interpret and give meaning to everyday life interactions (Denzin, 1992). Symbolic interactionism is founded in the works of Thomas (1918-1919, 1928/1970) and Mead (1934), and as well as the work of Blumer (1962, 1969).

- Phenomenology, which aims to understand the taken for granted assumptions of everyday life based on the subjective meanings that social actors construct to explain their social reality (Sarantakos, 1993). Phenomenology is firmly grounded in the subjective meanings that social actors construct to explain their social reality. Phenomenology is attributed to the work of Husserl and his student Schutz (1967).

- Ethnomethodology, which aims to understand the taken for granted structures of the world (Sarantakos, 1993). Ethnomethodology is grounded in the work of Garfinkel (1967), who coined the term, as well as the work of Zimmerman (1971). Ethnomethodology is an extension of the phenomenological work of Schutz applied to everyday life.

- Ethnography, the study of groups or people in their natural setting (Fetterman, 1989). Ethnography was the predominant domain used.

These domains were used in order to achieve what Weber (1978) calls verstehen-empathic understanding of the cruising women in this study (see the first aim and earlier reference to an emic understanding). Verstehen or "empathic or appreciative accuracy is attained when, through sympathetic participation, we can adequately grasp the emotional context in which the action took place" (Weber, 1978 , p. 5). In using both a feminist and an interpretive methodology, I was trying to ensure that "in attempting to do a social science, sociology [did not] become alienated from the social" (Mehan \& Wood, 
1975, p. 63). Subsequently, verstehen has links to ontology, epistemology, methodology, and axiology.

In concluding this section of the article, I outline my own social situatedness, by locating myself as a participant within the subculture of long-term ocean cruising. My social situatedness is related to my axiological stance (my morals, values, and ethics) and the overall purpose of this study - to gain insights into and make visible the lived experiences of these cruising women. I do this in order to demonstrate that "my vantage point" is grounded on "the same social relations that structure the everyday world experiences" (Cook \& Fonow, 1990, p.73) of the cruising women who participated in the study. Furthermore, I need to emphasize that my own experience was and is gendered as I am a woman who has participated in the subculture of long-term ocean cruisers and who now lives in the margins of that subculture, a subculture that has traditionally been dominated by men. In locating myself, I acknowledge my "biases and preconceived notions about how people behave and what they think" (Fetterman, 1989, p. 11). I also acknowledge my subjectivity, which impacts on my epistemological stance in this study. My subjectivity, as would be expected, is situated in my biography: a white, middle-class, AngloCeltic Australian woman, who chose to study within the parameters of this article, white, middle-class, Western women in heterosexual relationships in the process of pursuing a cruising lifestyle.

\section{Methods}

Having identified the overall paradigm of this study as interpretive and the methodologies as feminist and qualitative, with the latter being particularly informed by symbolic interactionism, phenomenology, ethnomethodology, and ethnography, the next task is to discuss the qualitative methods selected. My research used multiple methods because as Burns (1997) notes "ethnographic 'fieldwork' is not a homogenous method, but involves a variety of techniques for data collection" (p. 303). Additionally, feminist research also involves multiple methods (see Reinharz, 1992). Particularly, I used participant observation and in-depth interviews. In addition, some quantitative-based questionnaires were used to gather sociodemographic and budgeting data. In commencing a discussion of the qualitative meth- ods I used, I am mindful of Wolcott's (1990) statement:

in the past two decades, qualitative methods ... have come to be widely known and accepted. There is no longer a call for each researcher to discover and defend them anew, nor a need to provide an exhaustive review of the literature about such standard procedures as participant observation or interviewing. (p. 26)

Subsequently, the following subsections provide a brief overview of the methods used in the study.

\section{Participant Observation}

Participant observation has been described in research literature in a variety of ways (Adler \& Adler, 1983; Gans, 1982; Gold, 1969; Junker, 1960). Adler and Adler's (1983) model (peripheral membership, active membership, and complete membership) best describes my fieldwork. I was a complete participant in the subculture from 1986 through to 1992 , prior to commencement of formal research studies. This enabled me to achieve an insider's perspective. From 1992 to 1994, I maintained "active membership" within the cruising community and from 1994 to 2003 peripheral membership. Participant observation provided observations, field note recordings, interview materials, and documentary evidences. Further, my participation as a long-term ocean cruiser provided autobiographical texts founded on my private correspondence to family and friends, my vessel's logbook-cum-diary, audiotapes made for family and friends, photographs, slide collections, and souvenirs. These personal records of my cruising experience supplement my lived experience and, together, constitute my autobiography upon which I also drew to interpret the texts and actions of cruisers. Further, my autobiography enabled me to mediate the "tension between self and others, of generating a reflection on the fluctuating place of the subject within its community" (Molloy, 1991, p. 9)

\section{Interviews}

Interviews have been described by some as conversations (Benney \& Hughes, 1970; Dexter, 1970). Others such as Oakley (1981), however, consider such views of interviews as simplistic. For Oakley (1981) interviews are pseudoconversations that traditionally have set rules to follow. According to 
Oakley (1981), interviews need to be established on "a relationship of mutual trust" otherwise the outcomes of the interview will be "particularly dismal" (p. 56). Further, Oakley (1981) noted that interviews should be "non-hierarchical" with the interviewer adding "his or her own personal identity in the relationship" (p. 41).

In this study, semistructured interviews were used. These ranged from 1.5 to 3 hours in duration with the average duration being around 2 hours. The interviews usually started with grand tour questions (i.e., broad-based questions related to the interview) (Spradley \& McCurdy, 1972) to make the cruisers feel comfortable and set the context for the interview. Sometimes, I used group interviews because of time constraints or preference of participants. Reinharz (1992) reported that "sociologist Lillian Rubin wrote ... [of] the need to interview husbands and wives separately and privately because "women tend to discuss their feelings about their lives, their roles, and their marriages more freely when men are not present" " (p. 41). Wajcman (1983) also supported this view, although Wajcman claimed that "fruitful discussions can occur if both spouses are present. ... [since] interviewing husbands and wives separately has the disadvantage of obscuring how interaction occurs in the couple" (Reinharz, 1992, p. 41). I found in my study that during the process of interviewing women and men together elements of their transactions were able to be observed and additional information regarding types of roles and relationships was able to be ascertained through participant observation and through the cruising men and women's verbal exchanges with each other as they sought to clarify opinions, issues, or events. Moreover, I was also able to observe the nature of power and equality evident in their exchanges while bearing in mind that those could change when I left the social setting.

\section{Surveys}

Apart from participant observation and in-depth interviews, seven written questionnaires were used to gather descriptive data on cruisers' personal details; yacht details, an "in-port" budget, and four surveys based on tourism literature were used to gather touristic data on cruisers. Apart from providing an overview of the sociodemographics for this article, these materials did not further inform the body of this article and so are not described in any detail here.

\section{Empirical Material Interpretation}

Positivists and postpositivists may be more acquainted with the term data instead of empirical materials. However, as this study used the interpretive social sciences paradigm, the term empirical materials is used instead of data as the latter resonates of objectivity and a sense of something being acted upon (causal relationships) instead of being co-constructed (multiple realities). Further, as will be discussed, ethnography and grounded theory is about interpretation or (re)construction; subsequently, I will use the term interpretation as opposed to analysis.

Because "ethnographers look for patterns of thought and behaviour" (Fetterman, 1989, p. 92), the challenge for me was "to seek the essence of the life of the observed, to sum up, to find a central unifying principle" (Bruyn, 1963/1970, p. 316). Empirical materials were collected until a "qualitative isomorph" (Ford, 1975) was reached. More specifically, when a "qualitative informational isomorph" was achieved, or when "redundancy with respect to information" occurred (Lincoln \& Guba, 1985, pp. 233-234), empirical material collection stopped. This is also related to " 'theoretical sampling'-a cyclical process of data collection and interpretation, which continues until no new data [sic] is found only confirmation of previous themes/'theories' " (Punch, 1998, p. 167). It is a state when "theoretical saturation" is achieved (Strauss \& Corbin, 1998, p. 143). Experiential interpretation also assisted me in empirical material interpretation and the determination of when to cease collecting empirical materials. Experiential interpretation involves "the researcher, as a full participant, uses her/himself as a gauge of the significance and meaning of an event, by subsequently looking inward to examine personal feelings" (Metcalf, 1986, p. 40).

Empirical materials interpretation was primarily undertaken through content analysis of cruising literature, grounded theory analysis, and comparative analysis of empirical materials. "Grounded theory is both a strategy for research and a way of analyzing data" (Punch, 1998, p. 163). Specifically, it is a 
systematic qualitative research method (Strauss \& Corbin, 1998, p. 12), which enables the researcher to inductively generate theory from the phenomenon being studied. Theory is generated from categories grounded in the empirical materials collected and the development of relationships between categories and their properties as well as dimensions (Strauss \& Corbin, 1998). Consequently, grounded theory is ideographic (Neuman, 2000). It provides a symbolic representation or "thick description"; and "limited generalization is warranted" (Wolcott, 1990, p. 30).

To complement my use of grounded theory, I also used Pamphilon's (1999) zoom model of interpretation when considering empirical materials derived from interviews and for reporting the research. Her analytical framework contains four levels of interpretation:

- the "macro-zoom," which defines the dominant discourses in texts;

- the "meso-zoom," which gives clarity to themes and phrases and taken-for-granted assumptions, as well as silences and absences in textual accounts;

- the "micro-level," which concentrates on pauses and emotions evident in texts, and subsequently highlights 'linguistic incongruence' (DeVault, 1990, p. 97) or the inability of language to suitably express a person's experience; and

- the "interactional" level, which focuses on transactions and reactions during interviewing.

As Pamphilon (1999) comments, "so much can be lost when an oral account is transcribed into text, it is crucial that oral sources are always acknowledged as oral sources" (p. 3). The role of the researcher in oral interactions is important. The researcher needs to identify her personal and "political" role (MacKinnon, 1982) in the research act. The interactional level demands that the researcher must write him or herself into the text, hence my earlier reference and inclusion of social situatedness in the paradigm section.

A qualitative researcher will also use "crystallization" (Richardson, 1994); that is, the use of multiple "angles of repose" (methods, constructions, and reconstructions) to assist with the process of interpretation, and to ground emergent theory building in the empirical world from which it evolved. However, it should be noted that "crystallization deconstructs the traditional idea of validity, for now there can be no single, or triangulated truth" (Denzin \& Lincoln, 2000b, pp. 873-874). The "theory" that emerged in the course of this study was verified by women participants during empirical material collection and interpretation. A further angle of repose was my autobiographical experiences from having been a cruiser and subsequently being able to engage in heuristic processes and reflexivity. Still further, other women (and men) engaged in cruising attested to the "goodness of fit" (Denzin \& Lincoln, 1994) of the narrative I was building of the lived experiences of cruising women with their own lived experiences.

\section{(Re)presenting and "Reporting" the Research}

When considering the appropriate genre to construct this article-that is, my "report" of the two connected ethnographic studies (1992-1999 and 2000-2003) into long-term cruising women who travel because of relationships-I, like other qualitative researchers, am aware of the hegemony of the "scientific" report. As Miles and Huberman (1994) note, such a genre is extremely "schematic and constraining" for a qualitative researcher. For qualitative researchers, "there are . . many different styles of writing and no absolutely 'right' way" (Jorgensen, 1989 , p. 119). Bearing this in mind, and because ethnography was the primary process and grounded theory was utilized, as noted earlier I "will introduce the literature later than might otherwise be done" (Punch, 1998, p. 168). The literature in itself becomes further empirical materials for interpretation. Subsequently, the presentation of the literature review occurs at the end of this article within the discussion of the "findings" because this is in accord with the principle of grounded theory where theory is developed and grounded in the empirical materials (Punch, 1998) rather than driven by a priori theories.

Moreover, I have used "thick description and verbatim quotations ... the most identifiable features of ethnographic ... reports ... [to] help convey a sense of immediacy to the reader [and to] provide the reader with sufficient data to determine whether the ethnographer's interpretations and conclusions 
are warranted" (Fetterman, 1989, pp. 114-115). Reinharz (1992) supports this intention: "many feminist researchers who interview include quotations from the interviews in the research product in order to give the reader a sense of these people. When the interviewees 'speak for themselves' or 'use their own voice,' the reader is better able to understand" (p. 267). As a consequence, I have included hesitations in speech using emdashes and "uhms" and "arrhs." I have also borne in mind Glesne and Peshkin's (1992) advice: "leave in enough of such sounds and words to capture the person's speech, authentically, but not so much as to impose on a reader's patience" (p. 169).

In narrating my research, "I" is used as any other form indicates "a passive voice that elides agency from the endeavour of thinking and writing" (Hirsch \& Fox Keller, 1990, p. 3). Additionally, I have chosen to use the active voice rather than the passive voice, as Becker (1986) advocates that such an approach adds specificity to the written texts. I have also used the words "some cruising women" or "some cruisers" as well as occasionally "some cruising men." The intent of such usage is not to reflect a small number of social actors, though at times the numbers may be small, such as two or three. Instead "some" is used as it is more reflexive of the multiple realities of the cruising women being portrayed and their experiences.

\section{A Narrative of Long-term Ocean Cruising Women Traveling "Because of" Relationships}

As previously stated, the main focus of this article is to gain insight into and make visible the lived experience of long-term ocean cruising women, who were cruising to be with their partners. For such women, the rationale for their decision making had consequences for the nature and type of relationships cruisers maintained aboard cruising vessels and impacted on the roles and responsibilities assigned as well as the acquisition of cruising knowledge. Cruising woman 343 provides a summary comment on cruising relationships, from a woman's perspective:

In our early cruising we met a lot of boats with very unhappy women aboard, and uhm tried to figure out why they were so unhappy, because I love ... the sailing ... living on the boat, ... navigating I like it all so much . . I couldn't figure out why they were so unhappy. There were several things that I discovered that a lot of them were passengers, a lot of them the men did everything so the little women didn't have to do it at all. Most of them had lovely homes that they weren't living in, that they had to leave behind whether it was temporary or permanent. A lot, most of the unhappy ones, had not lived aboard before they left. They just stored the things, rented the house, got on this little boat and took off and it's a great adjustment as you know, living on a boat is much different to living in a house. And they, the adjustment was made all at the same time that they subjected themselves to offshore passages and I felt that was a real mistake. A lot of the boats, I have a very good galley ... designed to my specifications and it works real well. A lot of the women had to deal with galleys that really were horrors to work in. And I could understand why they felt like they did. A lot of them were terrified because if something happened to their husband they didn't know what to do with the boat. They didn't know how to navigate and so they were not only unhappy but they were afraid. So that's what I think about the women and I haven't seen anything to change my mind. The happiest women that are cruising are the ones who participate in the sailing and the whole lifestyle. (Cruising woman 343)

Consequently, one cruising woman's advice to would be cruisers was: "Does your husband or wife want to go?" (Cruising woman 333). This after all, appears to be the very essence of a successful cruising relationship, and the chief determinant of whether individuals in a partnership might be considered "caught in the irons" or "sailing wing and wing."

These two metaphors- "caught in the irons" and "sailing wing and wing"- - are two distinctly different sailing metaphors that capture both ends of a continuum regarding sailing relationships. As noted earlier, the sailing metaphor "caught in the irons" has two meanings. Both have relevance for this article and are reiterated here. The first refers to when a boat has moved into the "no go" zone-the boat is facing the same direction from which the wind is coming, resulting in the wind passing over the sails at an insufficient angle to enable the boat to make any forward motion or to move off the direction of the wind. Primarily, for some cruising women, this describes their position; because of their partner, they perceive that they are in a "no go" zone and cannot move off in any other direction apart from cruising (a direction in which they do not want to go). Another meaning is derived from the use of leg shackles as a punishment to encourage conformity aboard 
vessels. For some cruising women, cruising is a punishment as a result of "conforming" to their partner's desire to go cruising.

At the other end of the continuum are "sailing wing and wing" relationships. The sailing metaphor meaning here is "downhill" sailing or "cruising down the trades." The boat is traveling in the same direction as the wind, two sails are drawn out either side of the boat (like two wings) and balanced, and the boat moves forward with relative ease, well away from the "no go" zone. In "wing and wing" relationships, the partnership is in balance and both partners are working to achieve a shared goal (life plan), which is usually articulated in relation to having quality time with the partner while pursing a satisfying lifestyle. The decision to go cruising in both metaphorical contexts is based on relationships. For those who are "caught in the irons," only one person is going because of the relationship, the other is usually going for either one or a variety of reasons, such as a dream, a love of sailing, for challenge and adventure, to travel, or for freedom.

Subsequently, cruising relationships can be described using the two oppositional sailing metaphors. "Caught in the irons" relationships exhibit conflicts between personal aspirations (life plan) and personal and private space requirements, sailing ability, access to sailing and cruising knowledge. Such conflicts serve to precipitate two events: either the termination of both or one partner's participation in the lifestyle, or the reaching of a compromise, such as a specific time limit being placed on the overall cruising plan. "Sailing wing and wing" relationships, on the other hand, exhibit joint aspirations, joint value systems, and cohesion. Furthermore, it appears that cruising empowers and strengthens the relationships rather than resulting in their dissolution. Obviously, between these two extremes there are other positions that relationships may adopt depending on their proximity to either end of the continuum.

As the specific focus of this article is "caught in the irons" relationships, it is to this that our attention will now be turned. How were these types of relationships identified by cruising women? Within the overall cruising women who participated in interviews (i.e., 60 women), 10 women were cruising purely because of their relationship with their husbands. Participant observation from 1992 to 2003 empirically supports this reason for cruising. The following statements from cruising women provide further insight:

Okay, I guess I chose to go cruising because I married $306 \mathrm{~m}$, quite frankly, it wouldn't have been a choice if I were single or if I'd married a non-sailing person. I wasn't the sailor first in our relationship so uhm, I went cruising because that was 306m's dream, ... But it wasn't my life long dream. [spoken matter-of-factly] (Cruising woman 305)

The above demonstrates "marital obligation." The next comment is framed around "love":

Love is the biggest and the strongest thing, I love him and he wanted to do it, so I followed. [spoken with emotion] (Cruising woman 357)

However, sometimes the decision to cruise may have nothing to do with love. Instead it may have more to do with a need for belonging and the resultant power of the one partner to shape another's "life plan," as evidenced by cruising woman 371's narrative, wherein she reflects on cruisers who travel down the West Coast of America before traveling west across the Pacific on a circumnavigation:

I think that most of the females were talked-coerced in some instances-and those are the ones who have left the boat before Australia.-In fact, quite a few of them left the boat by Mexico.-The women have [just] left [they just didn't like cruising or sailing]. (Cruising woman 371)

In the above quote, the need to belong becomes secondary to the need for safety and security, although the need to be with a partner (belonging) can be managed without voyaging:

Why do I cruise? There's more than one reason. The main reason is to be with $362 \mathrm{~m}$ and of course I love all the places that he's traveling but ... He'll be- $-\mathrm{He}$ 's coming home when he reaches Singapore-he's just coming home. [spoken assertively without looking at her partner]

I've been on the boat when he gets there. He does the passages and I've usually flown to meet him wherever he happens to be and we stay and travel where ever it is by car, whatever. (Cruising woman 361)

In the above, we see evidence of a compromise, he sails, and she flies to meet him in port. Another compromise is a time limit: 
[This trip] has a TIME FACTOR of two years and I know my husband is working on me to extend it to three years, he is LUCKY to have two years. [spoken assertively] (Cruising woman 333)

Even with compromises, the lifestyle may not be successful for a partnership. Relationships may terminate and one of the cruisers becomes a solo sailor because the other partner does not like sailing and cruising. During fieldwork, I organized to interview an American cruising woman. On the day of the interview, she said that she would prefer not to be interviewed as she would not provide a positive view of cruising, that she had had enough and was leaving the boat and her husband and she was going home to America. I indicated that if she felt like talking I would still like to hear her story. She declined and I did not pursue the issue as she was becoming distraught and I changed roles from interviewer to female support. The next day she left Australia bound for home.

I am mindful of a gender-biased perspective of only men "influencing" women to adopt a cruising lifestyle. I therefore need to acknowledge here that in at least two partnerships the lifestyle was orchestrated by women, albeit that these types of relationships tended to be rare:

Look at me! I'm the one that wanted to go see the world. You didn't care. [spoken emphatically at her partner] (Cruising woman 371)

Finally, however, to iterate, the reason for some women adopting a cruising lifestyle that involves independent travel is "because of" relationships:

He's sailing around the world. I don't like living without him, so I'm here. (Cruising woman 367)

The emergence of a Marxist/socialist feminist critique grounded in long-term ocean cruising women's lived experiences.

As the focus of this article identifies, one of the interpretive themes found in the empirical materials was relationships and, in particular, love and belonging. As a result of further interpretation using Pamphilon's (1999) zoom model, a critique emerged grounded in the women's lived experiences that had synergy with a Marxist/socialist feminist perspective. Marxist and socialist feminist perspectives are based on the work of Engels (1972), who suggested that the subordination of women was a result of historical circumstances that were related to material (private property) and economic reasons. This differs from the view expressed by Marx. According to Barrett (1988), Marx considered that the differences between women and men are biologically based and that the family unit is a "natural" unit, while Engels accounted for the inequality of family units as being based on ownership of private property.

Two Marxist/socialist feminists who developed Engels work are Coontz and Henderson (1986). Both believed that the oppression of women was attributed to the differences in the roles assigned to men and women in the production of goods and services and not to reproduction (i.e., biological processes). Moreover, the change in ownership of property and accumulation and distribution of the same by men and not women, coupled with patrilocality (women residing with their husbands' kin), changed the nature of communal groups with equality between the sexes to one in which the men predominated.

Brenner, whose work explores her "theoretical concern with the relationship between social structure and human agency" (Laslett, Brenner, \& Arat, 1995, p. 1), adopted a different focus. Barrett (1980) advocates that "the consequences of the separation of the home and workplace for family, and for gender relations" (p. 179) are multiple. In particular, Barrett (1980) further advocates that:

the accompanying ideological processes have involved the establishment of the privatized domestic area of "the home" as the particular province of women and of "femininity" and maternalism. Women have become dependent upon the male wage in capitalism and this mediated dependence upon the wage is circumscribed by an ideology of emotional, psychical and "moral" dependence. (p. 179)

Foreman (1977) and Zarestsky (1976) similarly discuss a link between capitalist reproduction and an individual's psychological being. Foreman (1977), in particular, argues that the oppression of women has resulted from capitalism's division of domestic and nondomestic realms and the continued reification of that split through psychological processes. Foreman (1977) particularly criticizes Marxism for not understanding the role of psycho- 
logical processes in political action and social reification. Women's "psychical" and economic dependence on the male wage was evidenced among some cruisers as a justification of the various roles and responsibilities assigned to each of the genders aboard a vessel. The following cruising woman, who reported being financially dependent on her cruising partner, positions herself in the domestic sphere due to her partner's chauvinism. At a meso and interactive interpretation, her comment suggests that the domestic sphere is one in which she feels she can contribute, and which will also not challenge his dominance:

For our situation, $386 \mathrm{~m}$ is the complete male chauvinist. Okay though, I don't change oil. I can basically do anything I want to on the boat but I tend to do the cooking and the cleaning. (Cruising woman 385)

As she further notes in the following statement, this cruising woman has difficulty in challenging his dominance, which is essentially due to her economic dependence on him and the private ownership of the boat by her male partner. Both of these and her "emotional, psychical and 'moral' dependence" (Barrett, 1980, p. 179) on him contribute to her subordinated position in the cruising relationship. This causes problems for her in regard to decision making:

Finally we made the choice [of boat to buy], it wasreally was [strong emphasis on was] 386m's choice because it was his money and his boat. It makes it difficult when we are sailing because it is not a joint venture it produces a different feeling. $386 \mathrm{~m}$ is the owner, the skipper and calls the shots, I have to lobby to get my view across because it's his thing really. (Cruising woman 385)

Such a view resonates of several categories of oppression. Young (1990) provides us with a framework to identify those categories as "exploitation, marginalization, powerlessness, cultural imperialism and violence" (p. 40) Aside from the above cruising woman's narrative, other cruisers' narratives and participant observation provide more evidence of the applicability of most of Young's categories of oppression. Firstly, some of the cruising women are exploited in the provision of free labor in the domestic sphere-a sphere where tasks are much more time consuming in their preparation and in their completion. This exploitation is particu- larly exacerbated for women who are "dragged along."

Cruising women are also marginalized. They are marginalized because of their lack of financial stake in the cruising enterprise as well as their lack of knowledge regarding sailing, navigation, and mechanical maintenance. This latter circumstance also represents the reification process associated with cruising men's oppression of women. The cruising men deny women access to the requisite knowledge and skills prior to taking off cruising through two means. One is through the men's control of economic resources and the channeling of all the economic resources into the boat and cruising enterprise rather than into knowledge acquisition of their partners using paid instructors or educators. The other is attributed to the control of time and knowledge by cruising men wherein all time and knowledge is allocated to boat acquisition or preparation of the cruising enterprise rather than to educating and skilling their cruising partners.

Both the lack of cruising women's financial investment in the cruising enterprise and their lack of knowledge further marginalizes them from decision making and subsequently renders them powerless. As cruising woman 371 noted, some women "are along for the ride" - a ride they undertake because of their "commitment" to their husbands-a ride in which they are exploited and subordinated and powerless. Their powerlessness, however, has further ramifications for cruising women than just their powerlessness in the pursuit of the cruising enterprise. It can have dire life and death consequences if something should happen to their partners, the holders of all cruising knowledge. In such cases, their powerlessness means they are unable to get the boat and themselves to safety. For example, when Margaret Johnson's husband was lost overboard in a storm off Fiji during 1989 (Murphy, 1989), Johnson was unable to navigate and the Fijian Navy rescued her and her two small children (see Murphy, 1989, p. 4). Such subsequent subordination and oppression of women is considered irresponsible by some cruisers and by mainstream society, which from time to time is called upon to operate and pay for the SAR (search and rescue) operations for these persons who live in the margins of mainstream society.

Self-reports of cruising women indicate that they also suffer from cultural imperialism in the form of 
patriarchy. Patriarchal attitudes to cruising women relegate them to the position of "other" and of affirming their marginal positions; for example: "as co-owner (legally and financially) of our $28 \mathrm{ft}$ Wanderer, I have never found it funny when strangers by pass me to enquire of my partner regarding 'his' boat" (Yorke, 1992, p. 6).

Finally, in regard to the last of Young's categories, neither the women nor my participant observation provided evidence to support physical violence as a means of oppression. I do not mean to suggest that violence absolutely does not exist in cruising relationships; however, I have no evidence of it. I have, however, on numerous occasions observed violent acts of verbal and emotional abuse of cruising women by their cruising male partners. These acts tended to occur in challenging situations when the men expected the women to act with skills beyond their abilities. As a result, the women were abused for their incompetence-an incompetence that the men orchestrated through their various use of Young's categories of oppression. In the event that cruising women dared to challenge their partners' decision making, the verbal abuse some women received only served to reiterate their subordinate position (e.g., "This is my boat and you'll do as I say" or "Whose f . . ing boat is this anyway?"). Such verbal volleys emphasize the emotional, psychical, and financial dependence and their supposed moral obligation to their partners. Furthermore, cruising women reported such situations significantly contributed to their future nonparticipation in the sailing aspect of cruising.

Smith (1981), on the other hand, identifies women's oppression by men is a result of "the constitution of public versus private spheres of action, and the relegation of the domestic to that sphere which is outside history" (p. 7). Essentially, Smith sees the work of women as akin to the alienation workers experience under a capitalist state. Women's work is situated in the domestic sphere representing a personal service and is ahistorical (outside history). Consequently, in providing a personal service for their partners (and family), "women of all classes would seem to be involved in the reproduction of class relations, including their own repression in that system" (Stacey \& Price, 1981, pp. 120-121).

Primarily, cruising women are constrained within the domestic sphere-a sphere that is a site for op- pression as their partner exhibits power and authority both without and within this realm. The inequality in roles and responsibilities within cruising relationships is not dissimilar to land-based relationships; however, the oppression and subordination is heightened as the majority of cruising women have nil or limited cruising-related skills outside the domestic sphere. It should be noted that many of the women participated in watch systems and called their partners up on deck if there was a problem. However, this participation in the nondomestic sphere was taken on top of other activities associated with the domestic sphere, such as cooking and cleaning. For some women, their participation in the domestic sphere was further limited on some passages due to seasickness. This often forced their male partners to move into the domestic sphere to assume the roles and responsibilities of their seasick partners.

Even with relegation of women to primarily the domestic sphere, a sphere in which some men also assume authority and power, women seek to achieve some sense of connectivity with this "space" in which they find themselves. For example, some of these cruising women developed rituals associated with the preparation and serving of food. A certain amount of pomp and ceremony accompanied the delivering of food to the table. The order and process of serving the food placed the woman in control or in charge of orchestrating the meal or food sharing event. Some rituals emphasized the effort the women made in the galley in less than optimal conditions-such as sighing, body gestures, or refusing to eat the food once it has been prepared in a hot galley. The use of such rituals and activities, as Littlejohn (1981, p. 115) noted, are associated with women's attempts to regain or maintain status, control, and authority in the domestic domain. In their totality, these activities or rituals enable women to empower themselves and to gain some connectivity with their sense of place and the space in which they were living.

\section{Does a Marxist/Socialist Feminist Perspective Explain All Cruising Women?}

A Marxist/socialist feminist perspective does not explain all cruising women. As indicated by the title descriptor, "caught in the irons" is "one of the lived 
experiences." And as noted in the introduction, there is a multiplicity of primary, as well as secondary, reasons for going cruising. Based on the wider study from which this article is drawn, several feminist perspectives emerged from the empirical materials: radical feminist, liberal feminist, and postmodern feminist perspectives. However, each reflected an inadequacy to "truthfully" reflect the situation of all cruising women. Further, among some women there was a resistance against a gendered approach. Such opposition to feminism was espoused by one cruising woman in particular:

I realize that we are not very traditional yachties in a couple of respects, ... usually I find it's the man though I don't like getting into gender things. I'm totally against that. But generally, I think it is . . the man is the mechanic and not the woman and I am not a mechanic but I have had to be because bless him he can't use a screwdriver so someone has to do it. (Cruising woman 325)

Although this cruising woman and her partner espouse shared or joint conjugal roles, this woman was different from the other cruising women. She had equality and she also had power. She was not subordinated - she was the dominant (ruling) identity in their relationship. She knew this and did not wish to enter into a gender debate about it. From her perspective, to do so would have given voice to her emasculation of her partner, whom she loved very much. Why did she assume such a position? Because of love-because of the affective rather than the social domain. Other cruising women also subtly protected their partner's ego. Some of these women had better sailing or navigating skills than their partners' however, these women preferred to reify the dominant patriarchal nature of cruising for the sake of love and belonging.

This is a critical point; the previously mentioned feminist viewpoints in this article have not delved into this aspect of relationships, preferring instead to deconstruct women's experiences from an essentially sociological perspective. The affective domain must be given voice because most often neither inequality nor power analyses take into account "the issue of affect" (Stacey \& Price, 1981, p. 131). Affect in this situation refers to the emotions and feelings partners have for each other and how these contribute to the roles and responsibilities adopted or assigned aboard cruising vessels or to the establishment or maintenance of power relationships. This move into the individual psyche and away from social constructions of discourse related to roles and power and families indicates that interpretation needs to be interdisciplinary in order to gain a fuller understanding of cruiser relationships. As noted by Stacey and Price (1981) and Rowbotham (1982), sociological discourse on agency, for example, needs to be complemented by consideration of the effect feelings and emotions have on decision, non-decision making, or the shaping of people's will. For example, as already identified, love and belonging were expressed as reasons for going cruising:

Love is the biggest and the strongest thing, I love him and he wanted to do it, so I followed. (Cruising woman 357)

To be together. [Laughs] It is really, to be together, and to do things together and to have time enough to be together, yeah, that's mine [reason for going cruising]. (Cruising woman 477)

Penultimately, "interpretive ethnography is, to use Riceour's phrase, a matter of attributing 'a meaning to a meaning,' . . . all interpretation is, of necessity, comparative. We understand another's speech with reference to our construal of its context" (Rosaldo, 1980, p. 221). As ethnographers, we are challenged to make sense of the discourses we capture. Furthermore, as cruising woman 607 noted "how do we really know what happens we only have their words" upon which to make our judgments.

Within this article, I have applied my own "reference" and the "references" of other cruising woman to portray the cruising experiences of women who are engaged in long-term ocean cruising. These and other angles of repose used in the empirical material collection and interpretation assisted the crystallization process. Moreover, the interpretation is founded on my own cruising experiences, my participant observations, and my gender. Some cruising men may no doubt have views different from or be uncomfortable with the views presented here. As Miller (1976) notes:

dominant groups generally do not like to be told about or even quietly reminded of the existence of inequality. "Normally" they can avoid awareness because their explanation of the relationship becomes so well inte- 
grated in other terms; they can even believe that both they and the subordinate group share the same interests and, to some extent, a common experience. (pp. 6-8)

Such a belief is as "Smith ... argues ... socially and historically constituted, rooted in an ideology that attempts to mystify the social relations of the knower and the known through procedures that appear anonymous and impersonal. This aura of objectivity can be maintained so long as the object of knowledge, the "known" can be an "other," an alien object that does not reflect back on the knower" (Westkott, 1990, p. 61). This is what I have attempted to do to make visible the multiple realities of the cruising women and their contribution to a cruising lifestyle from their perspective in order to give them voice-to see these women as "full members of their social, economic and political worlds" (Weiner, 1976) without an overlay of "androcentric blinders" (Reinharz, 1992, p. 51). As Rose (1991) notes, women can be subjects and agents. In particular, cruising women are subjects who actively negotiate their space within a cruising lifestyle. In doing so, cruising women are able to achieve "empowered connectivity" (Jennings, 1999), that is, the action of exhibiting agency in order to determine the degree of connectivity with the space in which an individual currently finds her or himself.

\section{Conclusion}

This article has had a threefold purpose. Firstly, the article sought to provide insight into the lived experiences of long-term ocean cruising women who go cruising "because of" (Schutz, 1967) relationship commitments. Secondly, the article aimed to provide a model for conducting and reporting qualitative research informed by an interpretive social science paradigm. This paradigm enabled a holistic perspective to be achieved, which provided in-depth insight into the "because of" love and belonging reasons for women who adopted long-term ocean cruising as a way of life-a life that involves travel. The grounded interpretation used illuminated one facet of the multiplicity of travel motivations for cruising women. In so doing, it has applied a reflexive lens through which to consider established and related theories drawn from sociology, social psychology, and tourism as well as feminist perspectives. Subse- quently, the article has simultaneously provided some insight into understanding mainstream and marginal Western middle class society and the changing nature of those societies in regard to lifestyle choices related to travel experiences. Specifically, the article contributes knowledge to the "linkages between changes in society, tourist motivation and the translation of motive and expectation into holiday experiences" (Ryan, 1997, p. 47).

Relatedly, the article also makes visible the experiences of women involved in long-term travel experiences. This in turn adds to the growing body of tourism and travel literature investigating tourism and travel from a gendered perspective as well as from women's perspectives. In particular, the article has demonstrated that when trying to understand gender differences, methodologies need to complement research agendas as well as apply suitable epistemological positions for understanding to occur, hence the inclusion of a "feminist methodology." Further, the article has emphasized the need for synergy between ontology, epistemology, methodology, axiology, and the importance and acknowledgment of researcher social situatedness in qualitative and "feminist" research. As a consequence, and as noted previously, the article has provided a model of an interpretive social sciences informed study that has been reported using a narrative genre.

Moreover, the article, due to its focus, has given voice to one group of women and made their travel experiences visible. In particular, the article has highlighted the resultant impacts of these women's decision making based on love and belonging needs upon their relationships, roles, responsibilities, and knowledge acquisition within the course of cruising travel experiences. Based on this information, it is germane for the tourist industry to recognize that some people who travel may not be traveling in regard to any particular travel motive at all and that "issues of affect" need to be incorporated into consideration of planning, development, provision, and monitoring of tourism packages and services. The industry also needs to be mindful that gender differences have direct consequences in regard to (in)equality, power, and agency related to decision making and the nature of participation throughout the entire travel experience. Finally, gender differences along with other differences, such as cultural, ethnic, religious, socioeconomic background, physical abilities, and 
knowledge bases, are critical to the overall satisfaction experienced and reported by individuals in the course of travel experiences.

\section{Biographical Note}

Gayle Jennings is an Associate Professor of Tourism Management, in the Department of Tourism, Leisure, Hotel and Sport Management, Griffith Business School, at Griffith University, Gold Coast Campus, Australia. Her research interests include "quality tourism experiences," independent travelers and their experiences, marine tourism, sport tourism, as well as social and cultural impacts of tourism. Gayle's writings also include consideration of the theoretical paradigms that inform tourism research as well as use of qualitative, mixed methods, and indigenous research methodologies.

\section{References}

Adler, P. A., \& Adler, P. (1983). Shifts and oscillations in deviant careers: The case of upper-level drug dealers and smugglers. Social Problems, 31, 195-207.

Barrett, M. (1980). Women's oppression today: Problems in Marxist feminist analysis. London: Verso.

Barrett, M. (1988). Women's oppression today: The Marxist/ feminist encounter. London: Verso.

Becker, H. (1986). Writing for social scientists. Chicago, IL: University of Chicago Press.

Benney, M., \& Hughes, E. C. (1970). Of sociology and the interview. In N. K. Denzin (Ed.), Sociological methods: A source book (pp. 175-181). Chicago, IL: Aldine Publishing Company.

Berger P. L., \& Luckmann, T. (1981). The social construction of reality. Harmondsworth: Penguin Books.

Blumer, H. (1962). Society as symbolic interaction. In A. Rose (Ed.), Human behaviour and social processes: An interactionist approach (pp. 179-192). Boston, MA: Houghton Miffin.

Blumer, H. (1969). Symbolic interactionism. Englewood Cliffs, NJ: Prentice-Hall.

Bricknell, L. (1999). The trouble with feelings: Gender, sexualities, and power in a gender regime of competitive sailing. Journal of Sport and Social Issues, 23(4), 421438.

Bruyn, S. (1963). The methodology of participant observation. Human Organization, 22(3), 224-235. (Reprinted in Qualitative methodology: Firsthand involvement with the social world, pp. 305-327, Filstead, W. J., Ed., 1970, Chicago, IL: Markham)

Burns, R. B. (1997). Introduction to research methods (3rd ed.). Melbourne: Longman.

Cook, J. A., \& Fonow, M. M. (1990). Knowledge and women's interests. In J. McCarl Nielsen, (Ed.), Feminist research methods, exemplary readings in the social sciences (pp. 69-93). Boulder, CO: Westview Press.
Coontz, S., \& Hendersen, P. (Eds.). (1986). Women's work, men's property: The origins of gender and class. London: Verso.

Crawley, S. (1998). Gender, class and the construction of masculinity in professional sailing: A case study of the American women's team. International Review for the Sociology of Sport, 33(1), 33-42.

Denzin, N. K. (1992). Symbolic interactionism and cultural studies. Oxford: Blackwell.

Denzin, N. K., \& Lincoln, Y. S. (1994). Introduction: Entering the field of qualitative research. In N. K. Denzin \& Y. S. Lincoln (Eds.), Handbook of qualitative research (pp. 1-17). Thousand Oaks, CA: Sage.

Denzin, N. K., \& Lincoln, Y. S. (2000a). Introduction: The discipline and practice of qualitative research. In N. K. Denzin \& Y. S. Lincoln (Eds.), Handbook of qualitative research (2nd ed., pp. 1-29). Thousand Oaks, CA: Sage.

Denzin, N. K., \& Lincoln, Y. S. (2000b). The art and practices of interpretation, evaluation, and representation. In N. K. Denzin \& Y. S. Lincoln (Eds.), Handbook of qualitative research (2nd ed., pp. 871-875). Thousand Oaks, CA: Sage.

Dexter, L. A. (1970). Elite and specialized interviewing. Evanston, IL: Northwestern University Press.

Devault, M. (1990). Talking and listening from women's standpoint: Feminist strategies for interviewing and analysis. Social Problems, 37(1), 99-118.

Dreikurs, R. (1953). Fundamentals of Adlerian psychology. Chicago: Alfred Adler Institute.

Engels, F. (1972). The origin of the family, private property and the state. London: Lawrence \& Wishart.

Fetterman, D. M. (1989). Ethnography, step by step (Applied Social Research Methods Series, Vol. 17). Newbury Park, CA: Sage.

Ford, J. (1975). Paradigms and fairy tales: An introduction to the science of meanings (Vol. 1). London: Routledge and Kegan Paul.

Foreman, A. (1977). Femininity as alienation: Women and the family in Marxism and psychoanalysis. London: Pluto.

Gans, H. J. (1982). The participant observer as a human being: Observations on the personal aspects of fieldwork. In R. G. Burgess (Ed.), Field research: A sourcebook and a field manual (pp. 53-61). Boston, MA: George Allen and Unwin.

Garfinkel, H. (1967). Studies in ethnomethodology. Englewood Cliffs, NJ: Prentice-Hall.

Glesne, C., \& Peshkin, A. (1992). Becoming qualitative researchers. White Plains, NY: Longman.

Gold, R. L. (1969). Roles in sociological field observation. In G. J. McCall \& J. L. Simmons (Eds.), Issues in participant observation: A text and reader (pp. 30-38). Reading, MA: Addison Wesley.

Guba, E. C. (1990). The alternative paradigm dialog. In E. C. Guba (Ed.), The paradigm dialog (pp. 17-27). Newbury Park, CA: Sage.

Haraway, D. (1988). Situated knowledges: The science question in feminism and the privilege of partial perspective. Feminist Studies, 14, 3. 
Harding, S. (1991). Whose science? Whose knowledge? Milton Keyes: Open University Press.

Hirsch, M., \& Fox Keller, E. (1990). Introduction. In M. Hirsch \& E. Fox Keller (Eds.), Conflicts in feminism (pp. 1-5). New York: Routledge.

Jennings, G. R. (1999). Voyages from the centre to the margins: An ethnography of long term ocean cruisers. Unpublished doctoral thesis, Murdoch University, Perth, Australia.

Jorgensen, D. (1989). Participant observation: A methodology for a human studies (Applied Social Research Methods Series, Vol. 15). Newbury Park, CA: Sage.

Junker, B. H. (1960). Fieldwork: An introduction to the social sciences. Chicago, IL: University of Chicago Press.

King, K. (1990). Producing sex, theory, and culture: Gay/ straight remappings in contemporary feminism. In M. Hirsch \& E. Fox Keller (Eds.), Conflicts in feminism (pp. 82-101). New York: Routledge.

Laslett, B., Brenner, J., \& Arat, Y. (1995). Feminists rethink the political. In B. Laslett, J. Brenner, \& Y. Arat (Eds.), Rethinking the political: Gender, resistance, and the state (pp. 82-101). Chicago, IL: The University of Chicago Press.

Lett, J. (1983). Ludic and liminoid aspects of charter yacht tourism in the Caribbean. Annals of Tourism Research, 10, 35-56.

Lincoln, Y. S., \& Guba, E. G. (1985). Naturalistic inquiry. Newbury Park: Sage.

Linington, R. (1998). Towards an interpretation of a peculiar form of travel and tourism: Yacht chartering and sailing. Unpublished doctoral thesis, Roehampton Institute London, University of Surrey, UK.

Littlejohn, J. (1981). Westrigg: The sociology of a Cheviot Parish. In M. Stacey \& M. Price (Eds)., Women, power, and politics (p. 115). London: Tavistock Press.

Macbeth, J. (1985). Ocean cruising a study of affirmative deviance. Unpublished doctoral thesis, Murdoch University, Perth, Australia.

MacKinnon, C. A. (1982). Feminism, marxism, method, and the state: An agenda for theory. In N. O. Keohane, M. Z. Rosaldo, \& B. C. Gelphi (Eds.), Feminist theory: A critique of ideology (pp. 1-30). Chicago: The University of Chicago Press.

Mead, H. (1934). Mind, self and society (C. Morris, Ed.). Chicago: University of Chicago Press.

Mehan, H., \& Wood, H. (1975). The reality of ethnomethodology. New York: Wiley.

Metcalf, W. (1986). Dropping out and staying in: Recruitment, socialisation and commitment engendered in contemporary alternative lifestyles. Unpublished doctoral thesis. Griffith University, Australia.

Miles, M. B., \& Huberman, A. M. (1994). Qualitative data analysis: An expanded sourcebook (2nd ed.). Thousand Oaks, CA: Sage.

Miller, J. B. (1976). Toward a new psychology of women. Boston, MA: Beacon Press.

Molloy, S. (1991). At face value: Autobiographical writing in Spanish America. New York: Cambridge University
Press.

Murphy, T. (1989, November). From the Helm. Cruising Helmsman, 4-5.

Neuman, W. L. (2000). Social research methods, qualitative and quantitative approaches (4th ed.). Boston, MA: Allyn and Bacon.

Oakley, A. (1981). Interviewing women: A contradiction in terms. In H. Roberts, H. (Ed.), Doing feminist research (pp. 30-61). London: Routledge and Kegan Paul.

Pamphilon, B. (1999). The zoom model: A dynamic framework for the analysis of life histories. Qualitative Inquiry, 5(3), 393-410.

Punch, K. (1998). Introduction to social research, quantitative and qualitative approaches. London: Sage.

Reinharz, S. (1992). Feminist methods in social research. New York: Oxford University Press.

Richens, H. (1992). In B. Weiler \& C. M. Hall (Eds.), Special interest tourism (pp. 185-197). London: Belhaven Press.

Richardson, L. (1994). Writing: A method of inquiry. In N. K. Denzin \& Y. S. Lincoln (Eds.), Handbook of qualitative research (pp. 516-529). Thousand Oaks, CA: Sage.

Rosaldo, M. Z. (1980). Knowledge and passion: Ilongot notions of self and social life. Cambridge, UK: Cambridge University Press.

Rose, M. (1991). The post-modern and the post-industrial: A critical analysis. Cambridge, UK: Cambridge University Press.

Rowbotham, S. (1982). The trouble with patriarchy. In M. Evans (Ed.), The woman question (pp. 73-79). London: Fontana.

Ryan, C. (1997). The chase of a dream, the end of play. In C. Ryan (Ed.), The tourist experience: A new introduction (pp. 1-24, Studies in Tourism Series). London, UK: Cassell.

Sarantakos, S. (1993). Social research (1st ed.). South Melbourne: Macmillan.

Schutz, A. (1967). The phenomenology of the social world (G. Walsh and F. Lehnert, Trans.). Chicago, IL: Northwestern University Press.

Smith, D. (1981). Women, the family and corporate capitalism. In M. Stacey \& M. Price (Eds.), Women, power, and politics. London: Tavistock Press.

Spradley, J. P., \& McCurdy, D. W. (1972). The cultural experience: Ethnography in complex society. Chicago, IL: Science Research Association.

Stacey, M., \& Price, M. (1981). Women, power, and politics. London: Tavistock Press.

Strauss, A., \& Corbin, J. (1998). Basics of qualitative research: Techniques and procedures for developing grounded theory. Newbury Park, CA: Sage.

Thomas, W. I., \& Znaniecki, F. (1918-19). The Polish peasant in Europe and America. Chicago, IL: University of Chicago Press.

Thomas W. I., \& Swaine, T. D. (1970). The child in America: Behaviour problems and programs. New York: Alfred A Knopf. (Original work published 1928)

Wajcman, J. (1983). Women in control: Dilemmas of a work- 
ers' co-operative. New York: St Martin's Press.

Weber, M. (1978). Economy and society: An outline of interpretive sociology (Vol. 1). Berkerley, CA: University of California Press.

Weiner, A. (1976). Women of value, men of renown: New perspectives in Triobriand Exchange. Austin, TX: University of Texas.

Westkott, M. (1990). Feminist criticism of the social sciences. In J. McCarl Nielsen (Ed.), Feminist research methods, exemplary readings in the social sciences (pp. 58-68). Boulder, CO: Westview Press.

Wolcott, H. F. (1990). Writing up qualitative research (Quali- tative research methods series, Vol. 20). Newbury Park, CA: Sage.

Yorke, A. (1992, July). Man for all reasons (Letter to Editor). Cruising Helmsman, 6-7.

Young, I. M. (1990). Justice and the politics of difference. Princeton, NJ: Princeton University Press.

Zaretsky, E. (1976). Capitalism, the family and personal life. London, UK: Pluto Press.

Zimmerman, Donald. (1971). The practicalities of rule use. In J. D. Douglas (Ed.), Understanding everyday life (pp. 221-238). London: Routledge Kegan Paul. 